[Article]

\title{
理想与还原 $\mathrm{Fe}_{2} \mathrm{O}_{3}[001]$ 表面上录吸附协同催化 $\mathrm{CO}$ 分解作用
}

\author{
李继红 ${ }^{1}$ 林常枫 ${ }^{1}$ 覃 吴 ${ }^{1, *}$ 肖显斌 ${ }^{1}$ 魏 利 ${ }^{2, *}$ \\ ('华北电力大学可再生能源学院, 生物质发电成套设备国家工程实验室, 北京 102206 ; \\ 2哈尔滨工业大学, 城市水资源与水环境国家重点实验室, 哈尔滨 150090)
}

\begin{abstract}
摘要: 煤化学链燃烧必然释放录, 录与载氧体表面相互作用, 影响表界面的氧化还原反应。本文采用密度泛 函理论计算, 研究录 $\left(\mathrm{Hg}^{0}\right)$ 在理想表面 $\left(\mathrm{Fe}_{2} \mathrm{O}_{3}[001]\right)$ 和一系列被还原表面 $\left(\mathrm{Fe}_{2} \mathrm{O}_{2.75} 、 \mathrm{Fe}_{2} \mathrm{O}_{2.5} 、 \mathrm{Fe}_{2} \mathrm{O}_{2.25} 、 \mathrm{Fe}_{2} \mathrm{O}_{1.625}\right.$ 、 $\mathrm{Fe}_{2} \mathrm{O}_{0.875} 、 \mathrm{Fe}_{2} \mathrm{O}_{0.375}$ 和 $\mathrm{Fe}$ )的吸附, 以及 $\mathrm{Hg}^{0}$ 对 $\mathrm{Fe}_{2} \mathrm{O}_{1.625} 、 \mathrm{Fe}_{2} \mathrm{O}_{0.875} 、 \mathrm{Fe}_{2} \mathrm{O}_{0.375}$ 和 $\mathrm{Fe}$ 等表面催化 $\mathrm{CO}$ 分解反应的协 同作用机理。 $\mathrm{Hg}^{0}$ 物理吸附在理想 $\mathrm{Fe}_{2} \mathrm{O}_{3}$ [001]表面。随着 $\mathrm{Fe}_{2} \mathrm{O}_{3}$ [001]表面不断被还原, $\mathrm{Hg}^{0}$ 发生化学吸附。 $\mathrm{Hg}^{0}$ 吸附降低了 $\mathrm{CO}$ 与 $\mathrm{Fe}_{2} \mathrm{O}_{3} 、 \mathrm{Fe}_{2} \mathrm{O}_{2.75} 、 \mathrm{Fe}_{2} \mathrm{O}_{2.5}$ 和 $\mathrm{Fe}_{2} \mathrm{O}_{2.25}$ 等表面之间的相互作用, 抑制 $\mathrm{O}$ 传递氧化 $\mathrm{CO}$ 为 $\mathrm{CO}_{2}$ 的反应; 载氧体进一步还原过程中, $\mathrm{Hg}^{0}$ 吸附促进了 $\mathrm{CO}$ 与 $\mathrm{Fe}_{2} \mathrm{O}_{1.625} 、 \mathrm{Fe}_{2} \mathrm{O}_{0.875} 、 \mathrm{Fe}_{2} \mathrm{O}_{0.375}$ 及 $\mathrm{Fe}$ 等表面之间的 相互作用, 进而促进了表面对 $\mathrm{CO}$ 的催化分解反应, 加速了载氧体表面的积碳, 降低了化学链燃烧效率。因 此, 合理控制载氧体的还原程度既可以减弱 $\mathrm{Hg}^{\circ}$ 的吸附, 也可以抑制积碳的形成, 这对化学链燃烧的操作优 化至关重要。
\end{abstract}

关键词: 化学链燃烧; 载氧体; 永; $\mathrm{CO}_{2}$ 捕集; 密度泛函理论

中图分类号: 0647

\section{Synergetic Effect of Mercury Adsorption on the Catalytic Decomposition of $\mathrm{CO}$ over Perfect and Reduced $\mathrm{Fe}_{2} \mathrm{O}_{3}[001]$ Surface}

\author{
LI Ji-Hong ${ }^{1} \quad$ LIN Chang-Feng ${ }^{1} \quad$ QIN Wu ${ }^{1, *} \quad$ XIAO Xian-Bin ${ }^{1} \quad$ WEI Li ${ }^{2, *}$ \\ ('National Engineering Laboratory for Biomass Power Generation Equipment, School of Renewable Energy Engineering, \\ North China Electric Power University, Beijing 102206, P. R. China; ${ }^{2}$ State Key Laboratory of Urban Water Resource and \\ Environment, Harbin Institute of Technology, Harbin 150090, P. R. China)
}

\begin{abstract}
Mercury emission from coal during chemical-looping combustion (CLC) is an inevitable process, which can lead to adverse interactions with the surface of the oxygen carrier, thereby affecting the interfacial redox reactions. Density functional theory calculations were performed to investigate the mechanism of elemental mercury $\left(\mathrm{Hg}^{\circ}\right)$ adsorption and the synergetic effect of $\mathrm{Hg}^{0}$ on the catalytic decomposition of $\mathrm{CO}$ over a perfect surface $\left(\mathrm{Fe}_{2} \mathrm{O}_{3}[001]\right)$, as well as a series of reduced surfaces $\left(\mathrm{Fe}_{2} \mathrm{O}_{2.75}, \mathrm{Fe}_{2} \mathrm{O}_{2.5}, \mathrm{Fe}_{2} \mathrm{O}_{2.25}, \mathrm{Fe}_{2} \mathrm{O}_{1.625}\right.$, $\mathrm{Fe}_{2} \mathrm{O}_{0.875}, \mathrm{Fe}_{2} \mathrm{O}_{0.375}$ and $\mathrm{Fe}$ ) during a deep CLC process. In this study, $\mathrm{Hg}^{\circ}$ was physically adsorbed on to a perfect $\mathrm{Fe}_{2} \mathrm{O}_{3}$ surface, and then chemically adsorbed on to a series of reduced surfaces. The adsorption of $\mathrm{HgO}$ inhibited the formation of meaningful interactions between $\mathrm{CO}$ and $\mathrm{Fe}_{2} \mathrm{O}_{3}\left[\mathrm{Fe}_{2} \mathrm{O}_{2.75}, \mathrm{Fe}_{2} \mathrm{O}_{2.5}\right.$ and $\left.\mathrm{Fe}_{2} \mathrm{O}_{2.25}\right]$ and hindered the efficient transport of oxygen to oxidize $\mathrm{CO}$ into $\mathrm{CO}_{2}$. In contrast, this process promoted the interactions between $\mathrm{CO}$ and $\mathrm{Fe}_{2} \mathrm{O}_{1.625}\left[\mathrm{Fe}_{2} \mathrm{O}_{0.875}, \mathrm{Fe}_{2} \mathrm{O}_{0.375}\right.$, and $\left.\mathrm{Fe}\right]$, favoring the catalytic decomposition of $\mathrm{CO}$ on these surfaces, which accelerated the carbon deposit reducing CLC efficiency. Rationally controlling the reduction degree of the oxygen carrier could therefore be used to either decrease the adsorption of $\mathrm{Hg}^{0}$ or depress the deposition of carbon, which are both crucial for the optimization of CLC processes.
\end{abstract}

Received: May 3, 2016; Revised: July 27, 2016; Published online: July 27, 2016.

*Corresponding authors. QIN Wu, Email: qinwugx@126.com; Tel: +86-10-61772457. WEI Li, Email: weilihit@126.com; Fax: +86-451-86283805. The project was supported by the National Natural Science Foundation of China (51346001, 51106051) and Fundamental Research Funds for the Central Universities, China (2016YQ07, 2014ZD14).

国家自然科学基金(51346001, 51106051)和中央高校基本科研专项资金(2016YQ07, 2014ZD14)资助项目

(C) Editorial office of Acta Physico-Chimica Sinica 
Key Words: Chemical looping combustion; Oxygen carrier; Mercury; $\mathrm{CO}_{2}$ capture; Density functional theory

\section{Introduction}

In comparison with conventional combustion techniques and carbon dioxide removal techniques, chemical looping combustion (CLC) has received great attention because of its distinctive merit of efficient use of energy with in-situ $\mathrm{CO}_{2}$ capture ${ }^{1-3}$. CLC produces heat and energy using oxygen carriers (OCs), usually the oxides of $\mathrm{Fe}, \mathrm{Ni}, \mathrm{Co}, \mathrm{Cu}, \mathrm{Mn}$, and $\mathrm{Cd}$, to supply oxygen instead of air for the combustion of fuel. CLC of fuel results in generation of $\mathrm{CO}_{2}$ and $\mathrm{H}_{2} \mathrm{O}$ that is not diluted with $\mathrm{N}_{2}$ or flue gas, and reduces $\mathrm{NO}_{x}$ emissions $^{4-10}$. These properties render CLC highly desirable as possible candidate for low-cost coal combustion and carbon capture ${ }^{11-13} \cdot \mathrm{Fe}_{2} \mathrm{O}_{3}$ is the most promising OC used in CLC process due to its low cost and environmental compatibility ${ }^{14,15}$. Fig.1 depicts the schematic process of coal CLC using $\mathrm{Fe}_{2} \mathrm{O}_{3}$ as OC, where $\mathrm{Fe}_{2} \mathrm{O}_{3}$ is transferred from the air reactor (AR) to the fuel reactor (FR) to realize the full conversion of coal into $\mathrm{CO}_{2}$ and steam. After condensation, the pure $\mathrm{CO}_{2}$ can be obtained without extra energy consumption. The reduced $\mathrm{Fe}_{2} \mathrm{O}_{3-x}$ is transported back to the AR and regenerated therein for initiation of the next coal combustion cycle.

Nevertheless, coal CLC researches are at their very beginning, many problems and challenges lie ahead before their commercial adoption. For example, it is known that mercury exists in coal at the range of 0.02 to $1.0 \mathrm{mg} \cdot \mathrm{kg}^{-1}{ }^{16}$, which usually assumes three forms in flue gas: elemental mercury $\left(\mathrm{Hg}^{0}\right)$, oxidized mercury $\left(\mathrm{Hg}^{2+}\right)$, and particulate mercury $\left(\mathrm{Hg}^{\mathrm{p}}\right)$. Mercury is released into fuel gas as $\mathrm{Hg}^{0}$ during coal combustion ${ }^{17}$, emitted into the atmosphere, and then bioaccumulated through the food chain, which affects human health and generates long-lasting effects ${ }^{18}$. Mendiara detected the mercury released from CLC of coal and then quantitatively tested the emissions from the fuel reactor and air reactor ${ }^{19}$. However, whether there are certain interactions happening between mercury and OC during CLC processes, and if they have certain interactions, and how these interactions affect the related reactions of CLC process, remain unknown. Usually, OC could be generally reduced into lower oxidation state during deep CLC processes, and interfacial interactions would happen to these reduced OC surfaces. Therefore, it is necessary to detect the adsorption of mercury on the perfect and reduced OC surface at different reduction states, and the effect of mercury adsorption on the further reactions between

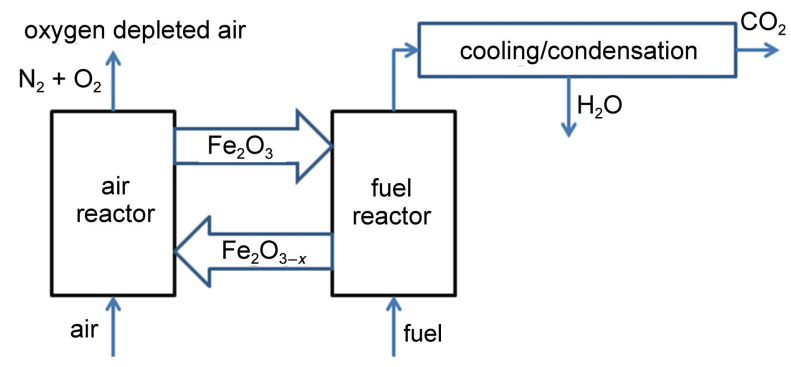

Fig.1 Schematic diagram for CLC of coal using $\mathrm{Fe}_{2} \mathrm{O}_{3}$ as $\mathrm{OC}$ fuel molecule and the reduced OC surface, which are fundamental understandings of the coal CLC system.

Considering that mercury firstly releases into fuel gas as $\mathrm{Hg}^{0}$ during coal combustion ${ }^{17}$, and $\mathrm{Fe}_{2} \mathrm{O}_{3}[001]$ is one of the dominant growth faces of the natural $\alpha-\mathrm{Fe}_{2} \mathrm{O}_{3}{ }^{18}$, we herein elucidated the detailed $\mathrm{Hg}^{0}$ adsorption on the gradually reduced $\mathrm{Fe}_{2} \mathrm{O}_{3}[001]$ surface and its effect on carbon deposition during CLC by using density functional theory (DFT) calculations. Results will provide insights into the mechanism of mercury adsorption and its effect on catalytic decomposition of $\mathrm{CO}$ during deep reduction of $\mathrm{Fe}_{2} \mathrm{O}_{3}$. The correlation between adsorption, decomposition, and reduction degree provides fundamental understanding to such complex CLC combustion processes. This study can serve as a reference for CLC optimization.

\section{Computational models and method}

\subsection{Theoretical models}

The pure $\mathrm{Fe}_{2} \mathrm{O}_{3}[001]-p(2 \times 2)$ surface with $32 \mathrm{Fe}$ atoms and 48 $\mathrm{O}$ atoms was modeled. To eliminate the spurious interaction between periodic images in the $z$ direction, the vacuum space is set no less than $1.5 \mathrm{~nm}$, and dipole correction is used as well. A series of reduced $\mathrm{Fe}_{2} \mathrm{O}_{3}[001]-p(2 \times 2)$ surfaces was obtained by gradually removing the $\mathrm{O}$ atoms on the outer surface layer to do annealing under constant pressure and temperature (NPT) until their equilibrium states were reached, where the initial temperature was 300 $\mathrm{K}$ and the mid-cycle temperature was $1073 \mathrm{~K}$ (the temperature for real CLC). Further geometric optimizations were performed using DFT calculations. After geometric optimization, the stable configurations of $\mathrm{Fe}_{2} \mathrm{O}_{3}, \mathrm{Fe}_{2} \mathrm{O}_{2.75}, \mathrm{Fe}_{2} \mathrm{O}_{2.5}, \mathrm{Fe}_{2} \mathrm{O}_{2.25}, \mathrm{Fe}_{2} \mathrm{O}_{1.625}, \mathrm{Fe}_{2} \mathrm{O}_{0.875}$, $\mathrm{Fe}_{2} \mathrm{O}_{0.377}$, and $\mathrm{Fe}$ are shown in Fig.2. Then the $\mathrm{Hg}^{0}$ adsorption, $\mathrm{CO}$ adsorption, and catalytic decomposition of $\mathrm{CO}$ on these surfaces were investigated.

\subsection{Parameters setting}

We used the CASTEP program package for all calculations performed with a plane-wave pseudo potential method based on dispersion-corrected $\mathrm{DFT}^{19}$, which was combined with the generalized gradient approximation (GGA) parameterized by Perdew, Burke, and Ernzerhof (PBE) ${ }^{20,21}$. Ultrasoft vanderbilt pseudopotentials ${ }^{22}$ were used to describe core orbitals. To correct the strong correlation between $3 d$-electrons of $\mathrm{Fe}$ atom, a Hubbard $U$ was adopted to provide an on-site Coulomb repulsion to the DFT Hamiltonian. Previous investigations suggested that DFT $+U$ method with $U=5 \mathrm{eV}$ could accurately reproduce the experimental value of bandgap (2.2 eV) and band structure of hematite $^{23-27}$. We have therefore adopted $U=5 \mathrm{eV}$ to conduct our calculations in this work. Previous studies have confirmed the cut-off energy of $350 \mathrm{eV}$ and $k$ meshes of $4 \times 4 \times 1$ in $\alpha-\mathrm{Fe}_{2} \mathrm{O}_{3}$ surface reaction field can obtain satisfied results ${ }^{28}$. Therefore, a cutoff of $350 \mathrm{eV}$ was employed with smearing width of $0.1 \mathrm{eV}$, while the Brillouin zone integration of the surfaces was calculated using 


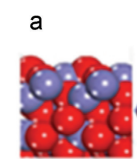

$\mathrm{Fe}_{2} \mathrm{O}_{3}$

e

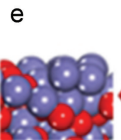

$\mathrm{Fe}_{2} \mathrm{O}_{1.625}$
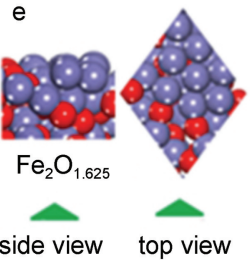

top view

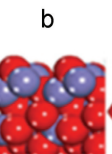

$\mathrm{Fe}_{2} \mathrm{O}_{2.75}$ $f$

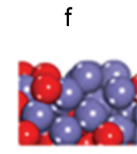

$\mathrm{Fe}_{2} \mathrm{O}_{0.875}$

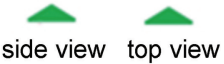

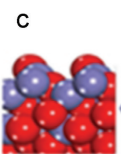

$\mathrm{Fe}_{2} \mathrm{O}_{2.5}$

g

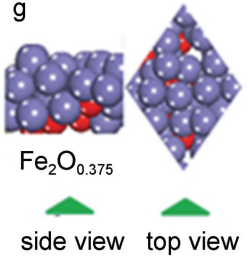

d
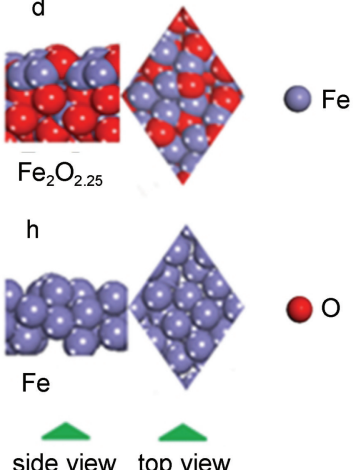

Fig.2 Top and side views of the perfect four-layer $\mathrm{Fe}_{2} \mathrm{O}_{3}[001]-p(2 \times 2)$ surface model (a) and the reduced surfaces:

(b) $\mathrm{Fe}_{2} \mathrm{O}_{2.636}$, (c) $\mathrm{Fe}_{2} \mathrm{O}_{2}$, (d) $\mathrm{Fe}_{2} \mathrm{O}_{1.364}$, (e) $\mathrm{Fe}_{2} \mathrm{O}_{0.909}$, (f) $\mathrm{Fe}_{2} \mathrm{O}_{0.182}$, and (g) $\mathrm{Fe}$

color online

$4 \times 4 \times 1$ Monkhorst-Pack $k$-point meshes. The magnetic configuration $(+--+)$ was set for $\mathrm{Fe}$ atoms in the rhombohedral unit cell of $\mathrm{Fe}_{2} \mathrm{O}_{3}$, which makes the optimized cell at the lowest total energy ${ }^{29-32}$, + and - designated up-spin and down-spin directions with respect to the $z$-axis. The convergence criteria for the structure optimization and energy calculation were set to (a) an energy tolerance of $2.0 \times 10^{-5} \mathrm{eV} \cdot$ atom $^{-1}$, (b) a SCF tolerance of $2.0 \times 10^{-6} \mathrm{eV} \cdot$ atom $^{-1}$, (c) a maximum force tolerance of $0.5 \mathrm{eV} \cdot$ atom $^{-1}$, and (d) a maximum displacement tolerance of $0.0002 \mathrm{~nm}$. A linear synchronous transit or quadratic synchronous transit approach (LST/QST) ${ }^{33}$ is used to get closer to the quadratic region of the transition state and then quasi-newton or eigenvector following methods are used to complete the optimization to ensure one and only one imaginary vibrational frequency.

The adsorption energy for the studied systems was calculated by using the following equation:

$$
E_{\text {ads }}=E_{\text {compound }}-E_{\text {slab }}-E_{\mathrm{x}}
$$

where $E_{\text {compound, }} E_{\text {slab}}$, and $E_{\mathrm{x}}$ are the total energy for the substrate with adsorbate, the substrate, and the adsorbate, respectively. More negative adsorption energy represents stronger interaction.

\section{Results and discussion}

\section{1 $\mathrm{Hg}^{0}$ adsorption on perfect and reduced $\mathrm{Fe}_{2} \mathrm{O}_{3}[001]$ surfaces}
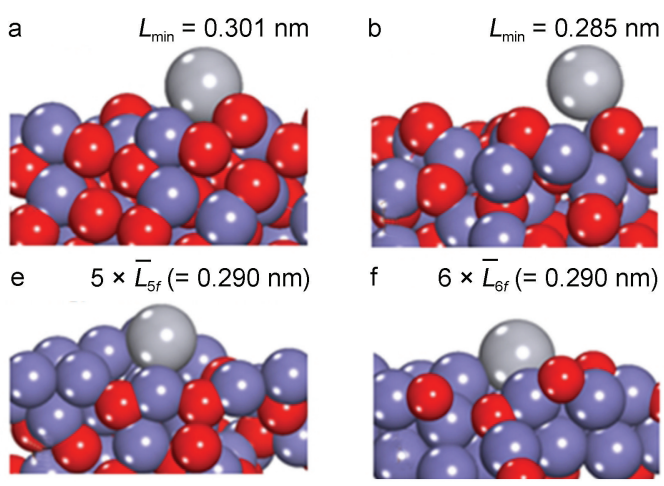

c
Since $\mathrm{Fe}_{2} \mathrm{O}_{3}[001]$ will be gradually reduced in the fuel reactor during CLC, the adsorptions of $\mathrm{Hg}^{0}$ on the perfect and the reduced $\mathrm{Fe}_{2} \mathrm{O}_{3}[001]$ surfaces were investigated. Previous work showed that $\mathrm{Hg}$ atom is more inclined to bind to $\mathrm{Fe}$ atom than $\mathrm{O}$ atom on oxide surface ${ }^{34}$. We approached $\mathrm{Hg}^{0}$ to different $\mathrm{Fe}$ atomic sites of these surfaces. Fig. 3 illustrated the most stable configurations for the $\mathrm{Hg}^{0}-\mathrm{Fe}_{2} \mathrm{O}_{3}, \mathrm{Hg}^{0}-\mathrm{Fe}_{2} \mathrm{O}_{2.75}, \mathrm{Hg}^{0}-\mathrm{Fe}_{2} \mathrm{O}_{2.5}, \mathrm{Hg}^{0}-\mathrm{Fe}_{2} \mathrm{O}_{2.25}, \mathrm{Hg}^{0}-\mathrm{Fe}_{2} \mathrm{O}_{1.625}, \mathrm{Hg}^{0}-$ $\mathrm{Fe}_{2} \mathrm{O}_{0.875}, \mathrm{Hg}^{0}-\mathrm{Fe}_{2} \mathrm{O}_{0.375}$, and $\mathrm{Hg}^{0}-\mathrm{Fe}$ adsorption systems, respectively.

The corresponding calculated adsorption energies are presented in Fig.4. For $\mathrm{Hg}^{0}-\mathrm{Fe}_{2} \mathrm{O}_{3}$ adsorption system, $\mathrm{Hg}^{0}$ is physically adsorbed on Fe-top site of $\mathrm{Fe}_{2} \mathrm{O}_{3}$ [001] surface with the minimum distance $\left(L_{\text {min }}\right)$ of $0.3012 \mathrm{~nm}$ and $E_{\text {ads }}$ of $-0.36 \mathrm{eV}$ close to the reported value of $-0.39 \mathrm{eV}^{34}$. Then, the interaction between $\mathrm{Hg}^{0}$ and reduced surface becomes stronger. For example, in the $\mathrm{Hg}^{0}$ $\mathrm{Fe}_{2} \mathrm{O}_{2.75}$ system, weak chemisorption happens between $\mathrm{Hg}^{0}$ and $\mathrm{Fe}$ atom of $\mathrm{Fe}_{2} \mathrm{O}_{2.75}$, with the $\mathrm{Hg}^{0}-\mathrm{Fe}$ bond length of $0.2846 \mathrm{~nm}$ and $E_{\text {ads }}$ of $-0.65 \mathrm{eV}$, while the $\mathrm{Hg}^{0}-\mathrm{Fe}_{2} \mathrm{O}_{2.5}$ with the bond length of $0.283 \mathrm{~nm}$ and $E_{\text {ads }}$ of $-0.76 \mathrm{eV}$. Further reduction of $\mathrm{Fe}_{2} \mathrm{O}_{2.5}$ into $\mathrm{Fe}_{2} \mathrm{O}_{2.25}, \mathrm{Fe}_{2} \mathrm{O}_{1.625}, \mathrm{Fe}_{2} \mathrm{O}_{0.875}, \mathrm{Fe}_{2} \mathrm{O}_{0.375}$, and $\mathrm{Fe}$ promotes the adsorption of $\mathrm{Hg}^{0}$ on these surfaces, resulting in forming multi-coordinated $\mathrm{Hg}-\mathrm{Fe}$ bonds on these surfaces. In the $\mathrm{Hg}^{0}-\mathrm{Fe}_{2} \mathrm{O}_{2.25}$ configuration, the $E_{\text {ads }}$ is $-1.04 \mathrm{eV}$ and two $\mathrm{Hg}-\mathrm{Fe}$ bonds $(0.275$ and $0.286 \mathrm{~nm})$ formed on the surface, giving the average value $\bar{L}_{2 f}$ of $0.280 \mathrm{~nm}$.

Fig.3 Stable configurations for $\mathrm{Hg}^{0}$ on (a) $\mathrm{Fe}_{2} \mathrm{O}_{3}[001]$, (b) $\mathrm{Fe}_{2} \mathrm{O}_{2.75}$, (c) $\mathrm{Fe}_{2} \mathrm{O}_{2.5}$, (d) $\mathrm{Fe}_{2} \mathrm{O}_{2.25}$, (e) $\mathrm{Fe}_{2} \mathrm{O}_{1.625}$, (f) $\mathrm{Fe}_{2} \mathrm{O}_{0.875}$, (g) $\mathrm{Fe}_{2} \mathrm{O}_{0.375}$, and (h) $\mathrm{Fe}$ color online 


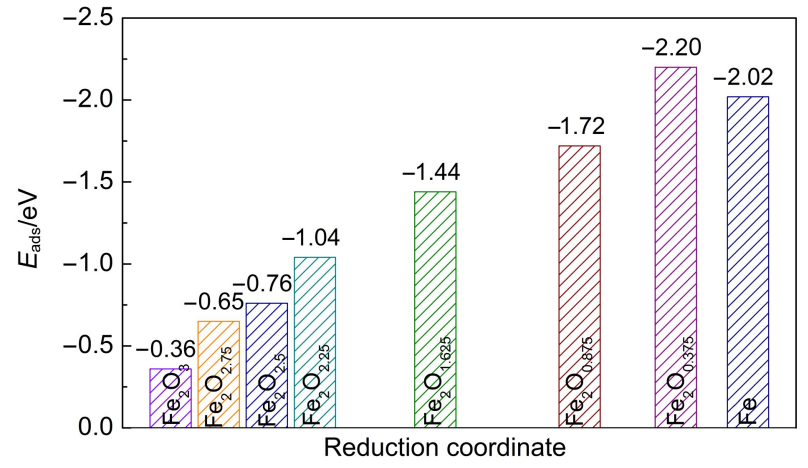

Fig.4 $E_{\text {ads }}$ for $\mathrm{Hg}^{\mathbf{0}}$ adsorption on the perfect and the reduced $\mathrm{Fe}_{2} \mathrm{O}_{3}[001]$ surfaces

In the $\mathrm{Hg}^{0}-\mathrm{Fe}_{2} \mathrm{O}_{1.625}$ configuration, the $E_{\text {ads }}$ is $-1.44 \mathrm{eV}$ and five $\mathrm{Hg}-\mathrm{Fe}$ bonds $(0.269,0.304,0.315,0.274$, and $0.287 \mathrm{~nm})$ formed on the surface, giving the average value $\bar{L}_{5 f}$ of $0.290 \mathrm{~nm}$. The $\mathrm{Hg}^{0}$ $\mathrm{Fe}_{2} \mathrm{O}_{0.875}, \mathrm{Hg}^{0}-\mathrm{Fe}_{2} \mathrm{O}_{0.375}$, and $\mathrm{Hg}^{0}-\mathrm{Fe}$ configurations show the average bond lengths $\bar{L}_{6 f}$ of $0.289 \mathrm{~nm}, \bar{L}_{6 f}$ of $0.279 \mathrm{~nm}, \bar{L}_{5 f}$ of $0.283 \mathrm{~nm}$, respectively, which result in the corresponding $E_{\text {ads }}$ of -1.72 , -2.20 , and $-2.02 \mathrm{eV}$. After $\mathrm{Fe}_{2} \mathrm{O}_{3}$ was reduced into the oxidation state that lower than $\mathrm{Fe}_{2} \mathrm{O}_{2}$ (such as $\mathrm{Fe}_{2} \mathrm{O}_{1.625}, \mathrm{Fe}_{2} \mathrm{O}_{0.875}, \mathrm{Fe}_{2} \mathrm{O}_{0.375}$, and $\mathrm{Fe}$ ), stable chemisorption appears, where $\mathrm{Hg}^{0}$ binds firmly to the Fe-accumulated area on the reduced surface.

To further understand the interaction between $\mathrm{Hg}^{0}$ and the surfaces, we analyzed the partial density of state (PDOS) of the adsorbed $\mathrm{Hg}^{0}$, which is plotted in Fig.5. As observed in Fig.5, $4 s$-DOS curve for the $\mathrm{Hg}^{0}$ adsorbed on $\mathrm{Fe}_{2} \mathrm{O}_{3}$ [001] overlaps to that for the pure $\mathrm{Hg}^{0}{ }^{35}$, while $4 s$-DOS for $\mathrm{Fe}_{2} \mathrm{O}_{2.75}$ and $\mathrm{Fe}_{2} \mathrm{O}_{2.5}$ splits around Fermi level $\left(E_{\mathrm{f}}=0 \mathrm{eV}\right)$ suggesting obvious electronic interaction between $\mathrm{Hg}^{0}$ and surface. Therefore, $\mathrm{Hg}^{0}-\mathrm{Fe}_{2} \mathrm{O}_{2.75}$ and $\mathrm{Hg}^{0}-\mathrm{Fe}_{2} \mathrm{O}_{2.5}$ can be assigned to chemisorption. With further reduction of $\mathrm{Fe}_{2} \mathrm{O}_{3}$ into $\mathrm{Fe}_{2} \mathrm{O}_{1.625}, \mathrm{Fe}_{2} \mathrm{O}_{0.875}, \mathrm{Fe}_{2} \mathrm{O}_{0.375}$, and $\mathrm{Fe}, 4 s$-DOS of $\mathrm{Hg}^{0}$ split into bonding orbital and anti-bonding orbital, implying that stronger interaction happens between $\mathrm{Hg}^{0}$ and surface. These results further verify that the interactions between $\mathrm{Hg}^{0}$ and the deeply reduced surfaces $\left(\mathrm{Fe}_{2} \mathrm{O}_{1.625}, \mathrm{Fe}_{2} \mathrm{O}_{0.875}, \mathrm{Fe}_{2} \mathrm{O}_{0.375}\right.$, and $\left.\mathrm{Fe}\right)$ are stronger than those between $\mathrm{Hg}^{0}$ and the surfaces at relatively higher oxidation state $\left(\mathrm{Fe}_{2} \mathrm{O}_{3}\right.$,

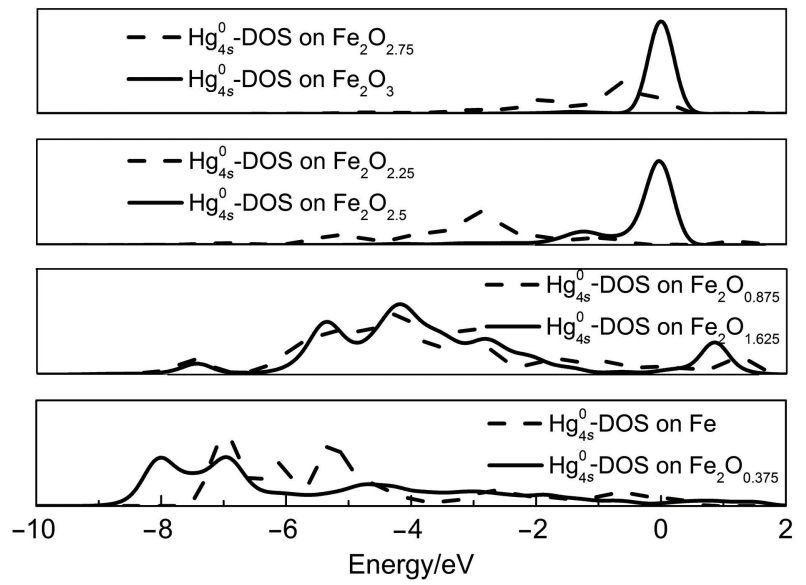

Fig.5 4s-DOS for the adsorbed $\mathrm{Hg}^{0}$ on the perfect and the reduced $\mathrm{Fe}_{2} \mathrm{O}_{3}[001]$ surfaces
$\mathrm{Fe}_{2} \mathrm{O}_{2.75}, \mathrm{Fe}_{2} \mathrm{O}_{2.5}$, and $\mathrm{Fe}_{2} \mathrm{O}_{2.25}$ ). Our results first reveal the relationship between the adsorption of $\mathrm{Hg}^{0}$ and the iron oxide surface at different reduction degrees. While iron oxide is used as oxygen carrier for coal combustion, deeper reduction of iron oxide into low oxidation state can result in higher adsorption quantity of $\mathrm{Hg}^{0}$.

Stable $\mathrm{Hg}^{0}$ adsorption alters the electronic property of the surfaces, which can hence affect the adsorption and decomposition processes of $\mathrm{CO}$. In our simulations, the stable $\mathrm{CO}$ chemisorption occurs through hybrid between $\mathrm{C}$ atom and $\mathrm{Fe}$ atom of surface, corresponding to that $\mathrm{CO}$ prefers to bind to transition metal site of the surface ${ }^{36,37}$. Fig. 6 compares the adsorption energies for the stable configurations of $\mathrm{CO}$ adsorption on $\mathrm{Fe}_{2} \mathrm{O}_{3}, \mathrm{Fe}_{2} \mathrm{O}_{2.75}, \mathrm{Fe}_{2} \mathrm{O}_{2.5}$, $\mathrm{Fe}_{2} \mathrm{O}_{2.25}, \mathrm{Fe}_{2} \mathrm{O}_{1.625}, \mathrm{Fe}_{2} \mathrm{O}_{0.875}, \mathrm{Fe}_{2} \mathrm{O}_{0.375}$, and $\mathrm{Fe}$ with and without the adsorption of $\mathrm{Hg}^{0}$, respectively. It can be observed that $E_{\text {ads }}$ shows an interesting trend for $\mathrm{CO}$ adsorption on $\mathrm{Fe}_{2} \mathrm{O}_{3}[001], \mathrm{Fe}_{2} \mathrm{O}_{2.75}$, $\mathrm{Fe}_{2} \mathrm{O}_{2.5}, \mathrm{Fe}_{2} \mathrm{O}_{2.25}, \mathrm{Fe}_{2} \mathrm{O}_{1.625}, \mathrm{Fe}_{2} \mathrm{O}_{0.875}, \mathrm{Fe}_{2} \mathrm{O}_{0.375}$, and $\mathrm{Fe}$, as the trend for $\mathrm{Hg}^{0}$ adsorption on these surfaces shown in Fig.4.

According to Fig.6, the reduced surfaces favor the adsorption of $\mathrm{CO}$ while compared to the perfect surface. With reduction of $\mathrm{Fe}_{2} \mathrm{O}_{3}$ into $\mathrm{Fe}, E_{\text {ads }}(-1.58 \mathrm{eV})$ for $\mathrm{CO}$ adsorption on $\mathrm{Fe}$ is close to the reported value of $-1.56 \mathrm{eV}$ for $\mathrm{CO}$ adsorption on $\mathrm{Fe}[110]^{38}$, but lower than the value $(-2.54 \mathrm{eV})$ for $\mathrm{CO}$ adsorption on $\mathrm{Fe}[100]^{39}$.

However, the adsorption of $\mathrm{Hg}^{0}$ decreases the interaction between $\mathrm{CO}$ and $\mathrm{Fe}_{2} \mathrm{O}_{3}\left[\mathrm{Fe}_{2} \mathrm{O}_{2.75}, \mathrm{Fe}_{2} \mathrm{O}_{2.5}\right.$, and $\left.\mathrm{Fe}_{2} \mathrm{O}_{2.25}\right]$, while promotes the interaction between $\mathrm{CO}$ and $\mathrm{Fe}_{2} \mathrm{O}_{1.625}\left[\mathrm{Fe}_{2} \mathrm{O}_{0.875}, \mathrm{Fe}_{2} \mathrm{O}_{0.375}\right.$, and $\mathrm{Fe}$. The distinct effect of $\mathrm{Hg}^{0}$ on $\mathrm{CO}$ adsorption can be attributed to the relativistic effect of $\mathrm{Hg}^{0}$. The band structure of the reduced surfaces shows that the band near and closed to the Fermi level between the $M$ and $K$ points in the brillouin zone is almost completely flat, indicating extremely high electron effective mass. While $\mathrm{Hg}^{0}$ chemically bound to $\mathrm{Fe}$ atoms of these reduced surfaces at relatively higher oxidation state, the bands near and closed to the Fermi level become less dispersive (for example, the band structures for $\mathrm{Fe}_{2} \mathrm{O}_{2.5}$ and $\mathrm{Hg}^{0}-\mathrm{Fe}_{2} \mathrm{O}_{2.5}$ in Fig. $1 \mathrm{Sa}$ (Supporting Information)), which depress electron and hole transport through the interface, hence decreasing the interaction between $\mathrm{CO}$ and the surface. During the first reduction stage (from $\mathrm{Fe}_{2} \mathrm{O}_{3}$ to $\mathrm{Fe}_{2} \mathrm{O}_{1.625}$ ), $\mathrm{Hg}^{0}$ acts as electron donor decreasing the oxidizability of the

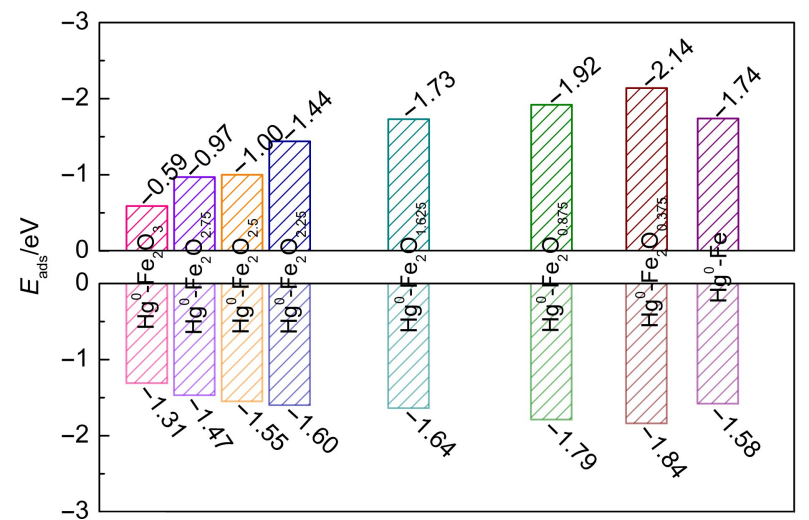

Fig.6 $E_{\text {ads }}$ for $\mathrm{CO}$ adsorption on the perfect and reduced $\mathrm{Fe}_{2} \mathrm{O}_{3}$ surfaces, and the perfect and reduced $\mathrm{Hg}^{0}-\mathrm{Fe}_{2} \mathrm{O}_{3}$ surfaces 
surfaces before $\mathrm{Fe}_{2} \mathrm{O}_{1.625}$. Then during the last reduction state (from $\mathrm{Fe}_{2} \mathrm{O}_{1.625}$ to $\mathrm{Fe}$ ), $\mathrm{Hg}^{0}$ chemically bound to $\mathrm{Fe}$ on the surfaces, the bands near and closed to the Fermi level become more dispersive (for example, the band structures for $\mathrm{Fe}_{2} \mathrm{O}_{0.375}$ and $\mathrm{Hg}^{0}-\mathrm{Fe}_{2} \mathrm{O}_{0.375}$ in Fig. $1 \mathrm{Sb}$ (in Supporting Information)), promoting electron and hole transport through the interface, where $\mathrm{Hg}^{0}$ acts as electron accepter increasing the oxidizability of the reduced surfaces favoring the hybridization between $\mathrm{C}$ and $\mathrm{Fe}$, hence promoting the interaction between $\mathrm{CO}$ and the reduced surface.

Fig.7 describes the relationship between the reduction degree, charge population (on $\mathrm{C}$ atom and $\mathrm{O}$ atom of the adsorbed $\mathrm{CO}$ molecule, and the total population on the adsorbed $\mathrm{CO}$ molecule), and bond length (of the adsorbed $\mathrm{CO}$ molecule and the new formed $\mathrm{Fe}-\mathrm{C}$ bond). Generally, it is accepted that strong interaction corresponds to high value of $E_{\text {ads }}$, lengthening of the $\mathrm{C}-\mathrm{O}$ bond, and obvious charge transport cross the interface. According to Fig.7a, little charge transfer happens on the perfect $\mathrm{Fe}_{2} \mathrm{O}_{3}$ and the $\mathrm{Hg}^{0}-\mathrm{Fe}_{2} \mathrm{O}_{3}$ surfaces, corresponding to small $E_{\text {ads }}$ value above, which verified the physisorption. Then charge transfer becomes more obvious with the reduction of the surface. The representative interaction district appears after $\mathrm{Fe}_{2} \mathrm{O}_{2.25}$, where the $E_{\text {ads, }}$, charge density transfers from surface to the adsorbed $\mathrm{CO}$ molecule, and the lengthening of $\mathrm{C}-\mathrm{O}$ bond is more obvious than the cases before $\mathrm{Fe}_{2} \mathrm{O}_{2.25}$. The strong interaction and activation of $\mathrm{CO}$ will favor the catalytic decomposition of $\mathrm{CO}$ and result in carbon deposit on surfaces of the reduced OC, corresponding to an obvious weight increase according to the thermogravimetric analysis of $\mathrm{CO}-\mathrm{Fe}_{2} \mathrm{O}_{3}{ }^{28}$. According to Fig. 7b, interaction between $\mathrm{CO}$ and the reduced $\mathrm{Hg}^{0}$-doped surface also lengthens the $\mathrm{CO}$ bond after $\mathrm{Hg}^{0}-\mathrm{Fe}_{2} \mathrm{O}_{2.25}$ with obvious charge transfer across the interface and charge repopulation during this reduction period, which hence activates the $\mathrm{CO}$ bond for further decomposition.

\subsection{Effect of mercury on catalytic CO decomposition}

It is generally agreed that, with the reduction of iron oxide, $\mathrm{CO}$ decomposes on the reduced surface and acts as the key step for carbon deposit during $\mathrm{CLC}^{40,41}$. Therefore, we considered the
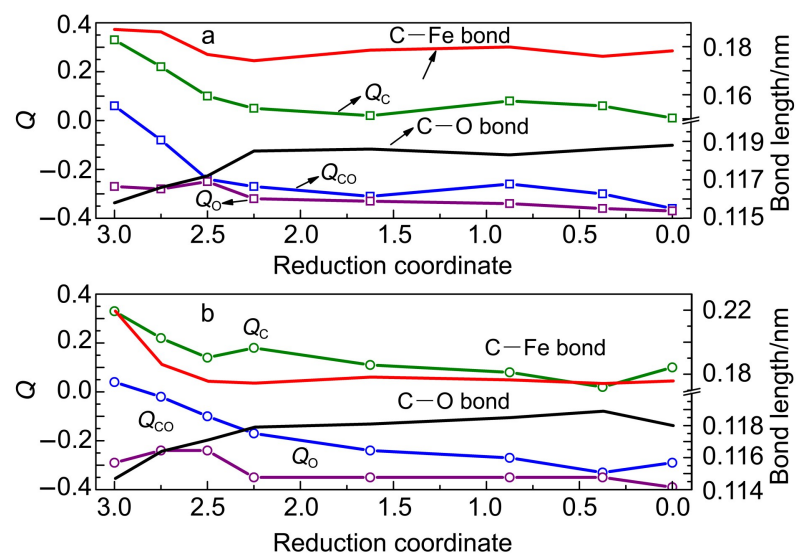

Fig.7 Charge population $(Q)$ for the $\mathrm{C}$ atom, $\mathrm{O}$ atom, and $\mathrm{CO}$ molecule, and the lengths of $\mathrm{C}-\mathrm{Fe}$ bond and $\mathrm{C}-\mathrm{O}$ bond

(a) over the perfect and reduced $\mathrm{Fe}_{2} \mathrm{O}_{3}$ surfaces, (b) over the perfect and reduced $\mathrm{Hg}^{0}-\mathrm{Fe}_{2} \mathrm{O}_{3}$ surfaces following reaction mechanism on the reduced $\mathrm{Fe}_{2} \mathrm{O}_{3}[001]$ surface $\mathrm{CO}+* \rightleftharpoons \mathrm{CO}^{*}$

$$
\mathrm{CO}^{*}+* \rightleftharpoons \mathrm{C}^{*}+\mathrm{O}^{*}
$$

where $*$ denotes a free step site. Catalytic decomposition of $\mathrm{CO}$ may result in a wide range of products. We have neglected the further interaction between $\mathrm{C}^{*}, \mathrm{O}^{*}$, and $\mathrm{CO}$ that forms $\mathrm{CO}_{2}$ or carbonate species on the reduced surface.

Since carbon deposit hardly generates on the iron oxide at high oxidation state ${ }^{28}$, and stable $\mathrm{Hg}^{0}$ adsorption happens on the reduced surfaces $\mathrm{Fe}_{2} \mathrm{O}_{1.625}, \mathrm{Fe}_{2} \mathrm{O}_{0.875}, \mathrm{Fe}_{2} \mathrm{O}_{0.375}$, and $\mathrm{Fe}$ (seen in Fig.3), we discussed the catalytic decomposition of $\mathrm{CO}$ on these reduced surfaces. The reaction initiates from the most stable $\mathrm{CO}$ adsorption models, and the product corresponds to the decomposition of $\mathrm{CO}^{*}$ into $\mathrm{C}^{*}$ and $\mathrm{O}^{*}$ at the most stable state. Then transition state (TS) search calculations were performed to detect the energy profiles for the $\mathrm{CO}^{*}$ decomposition reaction on these reduced surfaces with and without the adsorption of $\mathrm{Hg}^{0}$. The barrier energy $\left(E_{\mathrm{a}}\right)$ and reaction enthalpy $\left(E_{\mathrm{r}}\right)$ for the two reaction cases related to catalytic decomposition of $\mathrm{CO}$ on $\mathrm{Hg}^{0}$-doped surfaces and the undoped surfaces are listed in Fig.8. It is clear that the adsorption of $\mathrm{Hg}^{0}$ decreases the $E_{\mathrm{a}}$ for catalytic decomposition of $\mathrm{CO}$ on $\mathrm{Fe}_{2} \mathrm{O}_{1.625}, \mathrm{Fe}_{2} \mathrm{O}_{0.875}, \mathrm{Fe}_{2} \mathrm{O}_{0.375}$, and $\mathrm{Fe}$. For example, $E_{\text {a }}$ for catalytic $\mathrm{CO}$ decomposition on $\mathrm{Fe}_{2} \mathrm{O}_{1.625}, \mathrm{Fe}_{2} \mathrm{O}_{0.875}, \mathrm{Fe}_{2} \mathrm{O}_{0.375}$, and $\mathrm{Fe}$ are 3.01, 2.76, 1.43, and $1.51 \mathrm{eV}$, while the $E_{\mathrm{a}}$ for $\mathrm{Hg}^{0}-\mathrm{Fe}_{2} \mathrm{O}_{1.625}, \mathrm{Hg}^{0}-\mathrm{Fe}_{2} \mathrm{O}_{0.875}$, $\mathrm{Hg}^{0}-\mathrm{Fe}_{2} \mathrm{O}_{0.375}$, and $\mathrm{Hg}^{0}-\mathrm{Fe}$ are 2.60, 2.39, 1.07 , and $1.23 \mathrm{eV}$, respectively. $E_{\mathrm{a}}$ for $\mathrm{CO}$ decomposition on $\mathrm{Fe}$ is higher than that for $\mathrm{CO}$ dissociation on $\mathrm{Fe}(100)$ (1.14 eV reported by, ${ }^{38} 1.07 \mathrm{eV}$ reported by Sorescu et $a l^{42}$, and $1.14 \mathrm{eV}$ reported by Moon et al. ${ }^{43}$ ). The general decrease of $E_{\mathrm{a}}$ on the $\mathrm{Hg}^{0}$-doped reduce surfaces could be attributed to the obvious charge transfer and charge repopulation on the adsorbed $\mathrm{CO}$ that activates the $\mathrm{C}-\mathrm{O}$ bond for easier decomposition (as shown above in Fig.7b). Except for $\mathrm{CO}$ decomposition on Fe surface, the reaction energy is in proportion to the barrier energy for $\mathrm{CO}$ decomposition on the reduced iron oxide surfaces. $\mathrm{CO}$ decompositions on $\mathrm{Fe}_{2} \mathrm{O}_{1.625}$ and $\mathrm{Fe}_{2} \mathrm{O}_{0.875}$ are endothermic processes, which need high temperature acting as driving force for the reactions. However, the adsorption of $\mathrm{Hg}^{0}$ reduces the barrier energy for $\mathrm{CO}$ decomposition making the reaction exo-
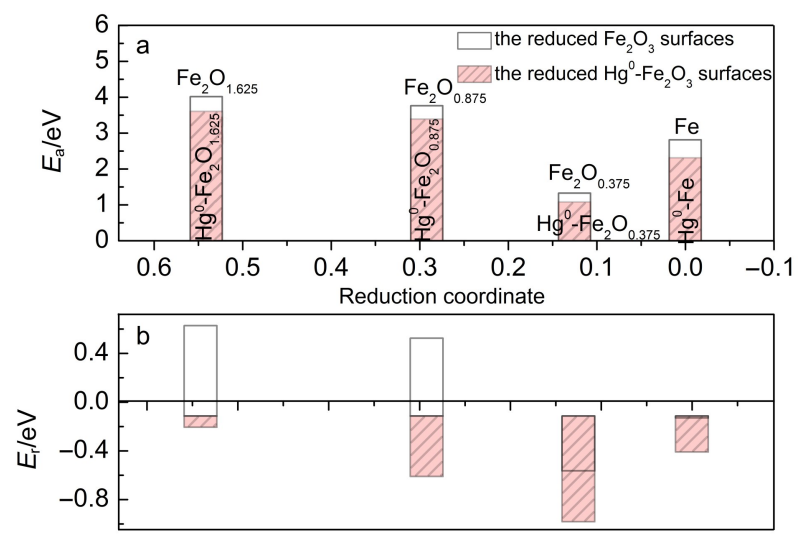

Fig.8 $\quad E_{\mathrm{a}}$ and $E_{\mathrm{r}}$ for $\mathrm{CO}$ adsorption on (a) the perfect and reduced $\mathrm{Fe}_{2} \mathrm{O}_{3}$ surfaces, and (b) the perfect and reduced $\mathrm{Hg}^{0}-\mathrm{Fe}_{2} \mathrm{O}_{3}$ surfaces 
thermic. Both kinetics and energetics analysis imply that carbon deposit is more energetically realized on the $\mathrm{Hg}^{0}$-doped reduced iron oxide surface.

Because of the low $E_{\mathrm{a}}$, obvious carbon deposit will happen after the reduction period around $\mathrm{Fe}_{2} \mathrm{O}_{1.625}$, which corresponds to the conversion rate $(\chi)$ around $46 \%$ (calculated by $\chi=\frac{m_{\mathrm{ox}}-m}{m_{\mathrm{ox}}-m_{\mathrm{red}}} \times$ $100 \%$, according to our previous works ${ }^{28,44,45}$ ). $\mathrm{Hg}^{0}$ promotes catalytic decomposition of $\mathrm{CO}$ for carbon deposit on the surfaces and depresses the efficiency of CLC.

To address the trends in $\mathrm{CO}^{*}$ decomposition more accurately, a kinetic model is required in order to treat the different time scales associated with the reduction of $\mathrm{Fe}_{2} \mathrm{O}_{3}$ at different degrees during CLC. We applied a simple phenomenological model to bring out the trends. The net reaction rates for reactions ( $\mathrm{R} 1$ and R2) are written as

$$
\begin{aligned}
& r_{1}=k_{1} \theta^{*} p_{\mathrm{CO}}-k_{-1} \theta_{\mathrm{CO}} \\
& r_{2}=k_{2} \theta_{\mathrm{CO}}-k_{-2} \theta_{\mathrm{C}} \theta_{\mathrm{O}}
\end{aligned}
$$

where $k_{i}(i=1,2)$ are forward rate constants for Reaction-1 and Reaction-2 while $k_{-i}(i=1,2)$ are the rate constants for the backward reactions. $p$ and $\theta$ denote the pressure and surface coverage, respectively. Specially, $\theta^{*}$ denotes the ratio of exposed active site.

The rate constants may be written as

$$
k_{i}=\frac{k_{\mathrm{B}} T}{h} \frac{f^{\ddagger}}{\prod f_{j}} \exp \left(\frac{-E_{i}}{R T}\right)
$$

where $E_{i}$ is the activation free energy of reaction step $i . h$ is the Planck constant $\left(6.63 \times 10^{-34} \mathrm{~J} \cdot \mathrm{s}\right), k_{\mathrm{B}}$ is Boltzmann constant $\left(1.38 \times 10^{-23} \mathrm{~J} \cdot \mathrm{K}^{-1}\right)$. The degree of freedom for the reaction component $j$ in each reaction step is given by

$$
f_{j}=f_{\mathrm{t}} \cdot f_{\mathrm{r}} \cdot f_{\mathrm{v}}
$$

where $f_{\mathrm{t}}, f_{\mathrm{r}}$, and $f_{\mathrm{v}}$ are the translational, rotational, and vibrational degree of freedom, respectively.

For the CO desorption step (the backward reaction of step (1)), we use a rate constant given by

$$
k_{-1}=v \exp \left(-\frac{E_{\mathrm{CO}}}{k_{\mathrm{B}} T}\right)
$$

where $E_{\mathrm{CO}}$ is the $\mathrm{CO}$ binding energy and $v=10^{13} \mathrm{~s}^{-1}$ is set as a typical pre-exponential factor for $\mathrm{CO}$ desorption.

With the above approximations, Reaction-2 is the rate-determining step for CO evolution. Since chemical looping combustion experiments were usually performed around $1073 \mathrm{~K}$ in our previous works ${ }^{28,45}$, the reaction rate is calculated according to the barrier energy for the decomposition of $\mathrm{CO}\left(\Delta E_{\mathrm{CO}^{*}}\right)$ under $1073 \mathrm{~K}$ and the given condition $\theta_{\mathrm{CO}}=0.5, \theta_{\mathrm{O}}=0.25, \theta_{\mathrm{C}}=0.25$, and $P_{\mathrm{CO}}=$ $1.01 \times 10^{5} \mathrm{~Pa}$. The results are shown in Fig.9. For the catalytic decomposition of $\mathrm{CO}$ on the reduced $\mathrm{Fe}_{2} \mathrm{O}_{3}$ surfaces (the red curve), high decomposition reaction rate can be realized during the period round $\mathrm{Fe}_{2} \mathrm{O}_{0.375}$ and closed to the complete reduction stage into iron. This red curve model describes the thermogravimetric trends observed experimentally well, where obvious weight increase due to carbon deposit occurred around and after $\mathrm{Fe}_{2} \mathrm{O}_{1.625}{ }^{28}$. However, $\mathrm{Hg}^{0}$ promotes the $\mathrm{CO}$ decomposition on these reduced surfaces (the black line). The adsorption of $\mathrm{Hg}^{0}$ promotes the cat-

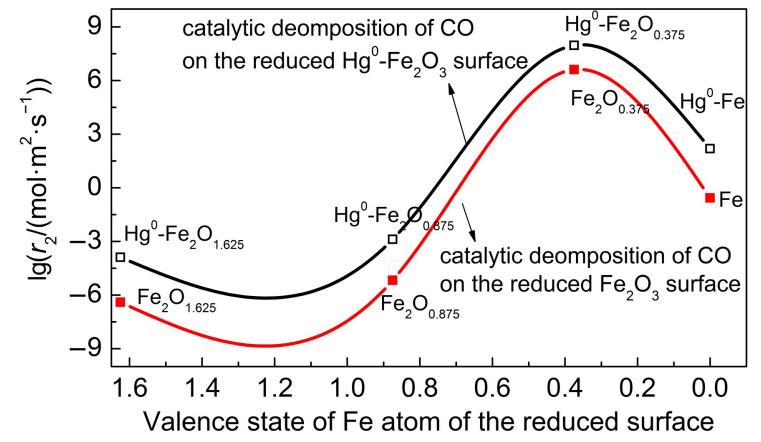

Fig.9 Reaction rate for $\mathrm{CO}$ decomposition on the reduced $\mathrm{Fe}_{2} \mathrm{O}_{3}[001]$ at $\theta_{\mathrm{CO}}=0.5, \theta_{\mathrm{O}}=0.25$, and $\theta_{\mathrm{C}}=0.25$ for the Reaction-2 under $1073 \mathrm{~K}$ color online

alytic decomposition of $\mathrm{CO}$, and reveals the relationship between catalytic $\mathrm{CO}$ decomposition reaction rate and reduction degree of iron oxide. The qualitative and quantitative results of $\mathrm{Hg}^{0}$ adsorption and its effect on $\mathrm{CO}$ adsorption and decomposition will provide fundamental understanding for optimizing the CLC processes.

\section{Conclusions}

We investigated the adsorption of elemental mercury $\left(\mathrm{Hg}^{0}\right)$ on the perfect and reduced $\mathrm{Fe}_{2} \mathrm{O}_{3}[001]$ surfaces, and probed into the synergetic effect of the adsorbed $\mathrm{Hg}^{0}$ on the catalytic decomposition of $\mathrm{CO}$ on the reduced $\mathrm{Fe}_{2} \mathrm{O}_{3}[001]$ surfaces during chemical looping combustion. Interaction between $\mathrm{Hg}^{0}$ and surface increases with reduction of $\mathrm{Fe}_{2} \mathrm{O}_{3}[001]$ into lower oxidation state. Stable $\mathrm{Hg}^{0}$ adsorption promotes the interaction between $\mathrm{CO}$ and the reduced surfaces, favoring charge transport from surface to the adsorbed $\mathrm{CO}$, which activates the $\mathrm{C}-\mathrm{O}$ bond for its decomposition. $\mathrm{Hg}^{0}$ together with carbon will hence be carried into air reactor, depressing the efficiency of CLC. Reasonable control of reduction degree not only hinders $\mathrm{Hg}^{0}$ binding to the surface of oxygen carrier but also decreases generation of carbon deposit. Results of the current DFT work provide fundamental understanding of interaction between $\mathrm{Hg}^{0}$ and the perfect and reduced $\mathrm{Fe}_{2} \mathrm{O}_{3}$ surfaces, and synergetic effect of $\mathrm{Hg}^{0}$ on the interaction between $\mathrm{CO}$ and these surfaces. For future studies, it is necessary to investigate the synergy of multiple elements included in coal such as $\mathrm{K}, \mathrm{Na}$, and $\mathrm{Ca}$ on mercury adsorption and its influence on the process of CLC.

Supporting Information: Band structures for $\mathrm{Fe}_{2} \mathrm{O}_{2.5}, \mathrm{Hg}^{0}$ $\mathrm{Fe}_{2} \mathrm{O}_{2.5}, \mathrm{Fe}_{2} \mathrm{O}_{0.375}$, and $\mathrm{Hg}^{0}-\mathrm{Fe}_{2} \mathrm{O}_{0.375}$, as well as geometric structures of initial state, transition state, and final state for $\mathrm{CO}$ decomposition on the reduced surfaces $\left(\mathrm{Fe}_{2} \mathrm{O}_{1.625}, \mathrm{Hg}^{0}-\mathrm{Fe}_{2} \mathrm{O}_{1.625}, \mathrm{Fe}_{2} \mathrm{O}_{0.875}, \mathrm{Hg}^{0}-\right.$ $\mathrm{Fe}_{2} \mathrm{O}_{0.875}, \mathrm{Fe}_{2} \mathrm{O}_{0.375}, \mathrm{Hg}^{0}-\mathrm{Fe}_{2} \mathrm{O}_{0.375}, \mathrm{Fe}$, and $\mathrm{Hg}^{0}-\mathrm{Fe}$ ) have been included. This information is available free of charge via the internet at http://www.whxb.pku.edu.cn.

\section{References}

(1) Horst, J. R.; Karl, F. K. Am. Chem. Soc. 1983, 7, 71.

(2) Ishida, M.; Jin, H. G. Ind. Eng. Chem. Res. 1996, 7, 2469. 
doi: $10.1021 / \mathrm{ie} 950680 \mathrm{~s}$

(3) Fan, L. S.; Zeng, L.; Wang, W.; Luo, S. W. Energy Environ. Sci. 2012, 5, 7254. doi: 10.1039/C2EE03198A

(4) Adanez, J.; Abad, A.; Garcia-Labiano, F.; Gayán, P.; de Diego, L. F. Prog. Energy Combust. Sci. 2012, 38, 215. doi: 10.1016/j. pecs.2011.09.001

(5) Zhang, Y.; Doroodchi, E.; Moghtaderi, B. Energy Fuels 2012, 26, 287. doi: 10.1021/ef201156x

(6) He, F.; Li, H. B.; Zhao, Z. L. Int. J. Chem. Eng. 2009, 2009, 1. doi: $10.1155 / 2009 / 710515$

(7) Lyngfelt, A.; Leckner, B.; Mattisson, T. Chem. Eng. Sci. 2001, 56, 3101. doi: 10.1016/S0009-2509(01)00007-0

(8) Fan, L. S.; Zeng, L.; Luo, S. W. AIChE J. 2015, 61, 2. doi: 10.1002/aic. 14695

(9) Tian, M.; Wang, X. D.; Liu, X.; Wang, A. Q.; Zhang, T. AIChE J. 2016, 62, 792. doi: 10.1002/aic.15135

(10) Cho, P.; Mattisson, T.; Lyngfelt, A. Fuel 2004, 83, 1215. doi: 10.1016/j.fuel.2003.11.013

(11) Abad, A.; Adánez, J.; García-Labiano, F.; de Diego, L. F.; Gayán, P.; Celaya, J. Chem. Eng. Sci. 2007, 62, 533. doi: 10.1016/j.ces.2006.09.019

(12) Cao, Y.; Pan, W. P. Energy Fuels 2006, 20, 1836. doi: 10.1021/ ef050228d

(13) Abad, A.; Cuadrat, A.; Mendiara, T.; García-Labiano, F.; Gayán, P.; de Diego, L. F.; Adánez, J. Ind. Eng. Chem. Res. 2012, 51, 16230. doi: $10.1021 / \mathrm{ie} 302158 \mathrm{q}$

(14) Zhang, S.; Xiao, R.; Zheng, W. G. Appl. Energy 2014, 130, 181. doi: 10.1016/j.apenergy.2014.05.049

(15) Xiao, R.; Song, Q. L.; Song, M.; Lu, Z. J.; Zhang, S.; Shen, L. H. Combust Flame 2010, 157, 1140. doi: 10.1016/j. combustflame.2010.01.007

(16) Yudovich, Y. E.; Ketris, M. P. Int. J. Coal Geol. 2005, 62, 107. doi: $10.1016 /$ j.coal.2004.11.002

(17) Frandsen, F.; Dam-Johansen, K.; Rasmussen, P. Prog. Energy Combust. Sci. 1994, 20, 115. doi: 10.1016/0360-1285(94)90007-8

(18) Thevuthasan, S.; Kim, Y. J.; Yi, S. I.; Chambers, S. A.; Morais, J.; Denecke, R.; Fadley, C. S.; Liu, P.; Kendelewicz, T.; Brown, G. E, Jr. Surf. Sci. 1999, 425, 276. doi: 10.1016/S0039-6028(99) 00200-9

(19) Segall, M. D.; Lindan, P. J. D.; Probert, M. J.; Pickard, C. J.; Hasnip, P. J.; Clark, S. J.; Payne, M. C. J. Phys.: Condens. Matter 2002, 14, 2717. doi: 10.1088/0953-8984/14/11/301

(20) White, J.; Bird, D. Phys. Rev. B. 1994, 50, 4954. doi: 10.1103/ PhysRevB.50.4954

(21) Perdew, J. P.; Chevary, J. A.; Vosko, S. H.; Jackson, K. A.; Pederson, M. R.; Singh, D. J.; Fiolhais, C. Phys. Rev. B: Condens. Matter Mater. Phys. 1992, 46, 6671. doi: 10.1103/ PhysRevB.46.6671

(22) Vanderbilt, D. Phys. Rev. B 1990, 41, 7892. doi: 10.1103/ PhysRevB.41.7892

(23) Guo, H.; Barnard, A. S. Phys. Rev. B 2011, 83, 094112. doi: 10.1103/PhysRevB.83.094112

(24) Bandyopadhyay, A.; Velev, J.; Butler, W. H.; Sarker, S. K.;
Bengone, O. Phys. Rev. B 2004, 69, 174429. doi: 10.1103/ PhysRevB.69.174429

(25) Huda, M. N.; Walsh, A.; Yan, Y. J. Appl. Phys. 2010, 107, 123712. doi: 10.1063/1.3432736

(26) Dzade, N. Y.; Roldan, A.; de Leeuw, N. H. Minerals 2014, 4, 89. doi: $10.3390 / \min 4010089$

(27) Rohrbach, A.; Hafner, J.; Kresse, G. Phys. Rev. B 2004, 70, 125426. doi: 10.1103/PhysRevB.70.125426

(28) Qin, W.; Wang, Y.; Lin, C. F.; Hu, X. Q.; Dong, C. Q. Energy Fuels 2015, 29, 1210. doi: 10.1021/ef5024934

(29) Song, J. J.; Niu, X. Q.; Ling, L. X.; Wang, B. J. Fuel Process Technol. 2013, 115, 26. doi: 10.1016/j.fuproc.2013.04.003

(30) Wong, K.; Zeng, Q. H.; Yu, A. B. J. Phys. Chem. C 2011, 115, 4656. doi: 10.1021/jp1108043

(31) Martin, G. J.; Cutting, R. S.; VauGhan, D. J.; Warren, M. C. Am. Mineral. 2009, 94, 1341. doi: 10.2138/am.2009.3029

(32) Sandratskii, L. M.; Uhl, M.; Kübler, J. J. Phys.: Condens. Matter 1996, 8, 983. doi: 10.1088/0953-8984/8/8/009

(33) Govind, N.; Petersen, M.; Fitzgerald, G.; King-Smith, D.; Andzelm, J. Comput. Mater. Sci. 2003, 28, 250. doi: 10.1016/ S0927-0256(03)00111-3

(34) Guo, P.; Guo, X.; Zheng, C. G. Fuel 2011, 90, 1840. doi: 10.1016/j.fuel.2010.11.007

(35) Ji, W. C.; Shen, Z. M.; Fan, M. H.; Su, P. R.; Tang, Q. L.; Zou, C. Y. Chem. Eng. J. 2016, 283, 58. doi: 10.1016/j. cej.2015.06.033

(36) He, F.; Wang, H.; Dai, Y. N. J. Nat. Gas. Chem. 2007, 16, 155. doi: 10.1016/S1003-9953(07)60041-3

(37) Dong, C. Q.; Sheng, S. H.; Qin, W.; Lu, Q.; Zhao, Y.; Wang, X. Q.; Zhang, J. J. Appl. Surf. Sci. 2011, 257, 8647. doi: 10.1016/j. apsusc. 2011.05 .042

(38) Stibor, A.; Kresse, G.; Eichler, A.; Hafner, J. Surf. Sci. 2002, 507, 99. doi: 10.1016/S0039-6028(02)01182-2

(39) Bromfield, T. C.; Ferré, D. C.; Niemantsverdriet, J. W. ChemPhysChem 2005, 6, 254. doi: 10.1002/cphc.200400452

(40) Claridge, J. B.; Green, M. L. H.; Tsang, S. C.; York, A. P. E.; Ashcroft, A. T.; Battle, P. D. Catal. Lett. 1993, 22, 299. doi: 10.1007/BF00807237

(41) Wang, B. W.; Yan, R.; Lee, D. H.; Liang, D. T.; Zheng, Y.; Zhao, H. B.; Zheng, C. G. Energy Fuels 2008, 22, 1012. doi: 10.1021/ ef7005673

(42) Sorescu, D. C.; Thompson, D. L.; Hurley, M. M.; Chabalowski, C. F. Phys. Rev. B 2002, 66, 035416. doi: 10.1103/ PhysRevB.66.035416

(43) Moon, D. W.; Bernasek, S. L.; Lu, J. P.; Gland, J. L.; Dwyer, D. J. Surf. Sci. 1987, 184, 90. doi: 10.1016/S0039-6028(87)80274-1

(44) Qin, W.; Lin, C. F.; Long, D. T.; Xiao, X. B.; Dong, C. Q. Acta Phys. -Chim. Sin. 2015, 31, 667. [覃 吴, 林常枫, 龙东腾, 肖显 斌, 董长青. 物理化学学报, 2015, 31, 667.] doi: 10.3866/PKU. WHXB201502061

(45) Dong, C. Q.; Liu, X. L.; Qin, W.; Lu, Q.; Wang, X. Q.; Shi, S. M.; Yang, Y. P. Appl. Surf. Sci. 2012, 258, 2562. doi: 10.1016/j. apsusc.2011.10.092 
Supporting Information for Acta Phys. -Chim. Sin. 2016, 32 (11), 2717-2723

doi : $\quad$ 10. 3866/PKU. WHXB201607271

\title{
理想与还原 $\mathrm{Fe}_{2} \mathrm{O}_{3}[001]$ 表面上录吸附协同催化 $\mathrm{CO}$ 分解作用
}

\author{
李继红 $^{1} \quad$ 林常枫 $^{1}$ 覃 吴 ${ }^{1, *}$ 肖显斌 ${ }^{1}$ 魏 利 ${ }^{2, *}$ \\ ( ${ }^{1}$ 华北电力大学可再生能源学院, 生物质发电成套设备国家工程实验室, 北京 102206 ; \\ 2 哈尔滨工业大学, 城市水资源与水环境国家重点实验室, 哈尔滨 150090)
}

\section{Synergetic Effect of Mercury Adsorption on the Catalytic Decomposition of $\mathrm{CO}$ over Perfect and Reduced $\mathrm{Fe}_{2} \mathrm{O}_{3}[001]$ Surface}

\author{
LI Ji-Hong $^{1} \quad$ LIN Chang-Feng ${ }^{1} \quad$ QIN Wu $^{1, *} \quad$ XIAO Xian-Bin $^{1} \quad$ WEI Li $^{2, *}$ \\ $\left({ }^{1}\right.$ National Engineering Laboratory for Biomass Power Generation Equipment, School of Renewable Energy \\ Engineering, North China Electric Power University, Beijing 102206, P. R. China; ${ }^{2}$ State Key Laboratory of \\ Urban Water Resource and Environment, Harbin Institute of Technology, Harbin 150090, P. R. China)
}

${ }^{*}$ Corresponding authors. QIN Wu, Email: qinwugx@126.com; Tel: +86-10-61772457.

WEI Li, Email: weilihit@126.com; Fax: +86-451-86283805. 

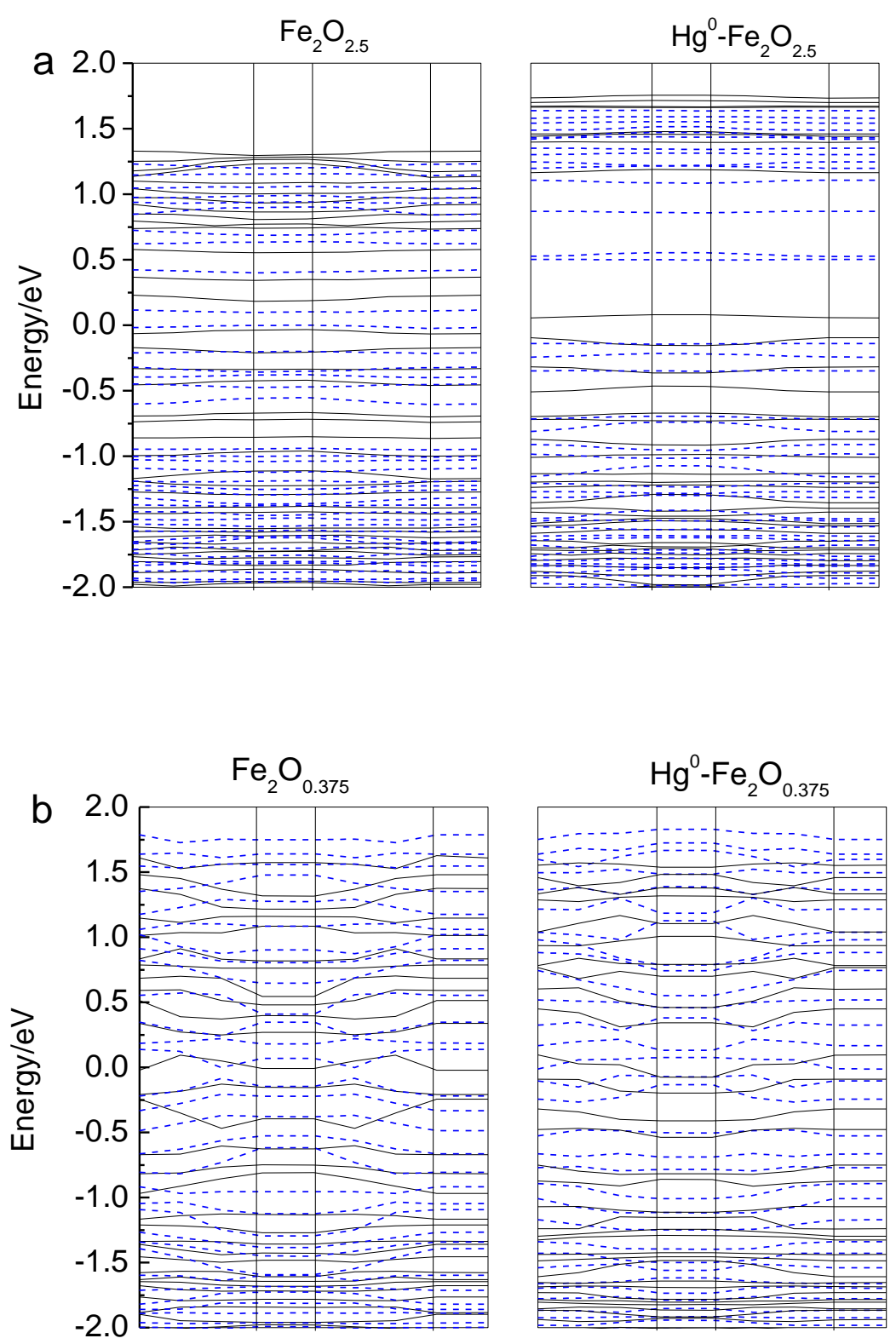

Fig.S1 Band structures for (a) $\mathrm{Fe}_{2} \mathrm{O}_{2.5}$ and $\mathrm{Hg}^{0}-\mathrm{Fe}_{2} \mathrm{O}_{2.5}$ and (b) $\mathrm{Fe}_{2} \mathrm{O}_{0.375}$ and $\mathrm{Hg}^{0}-\mathrm{Fe}_{2} \mathrm{O}_{0.375}$ 

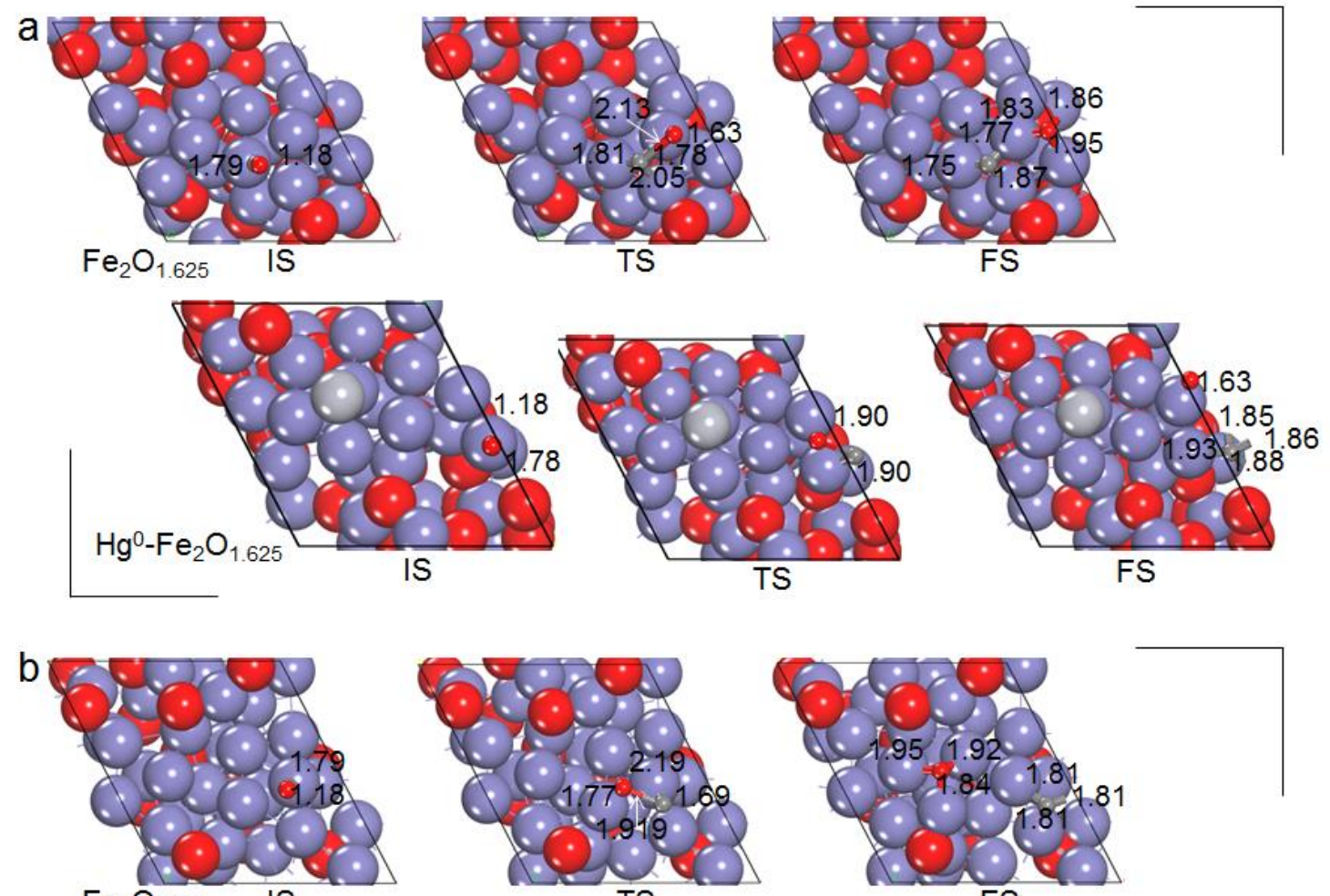

$\mathrm{Fe}_{2} \mathrm{O}_{0.875}$ IS
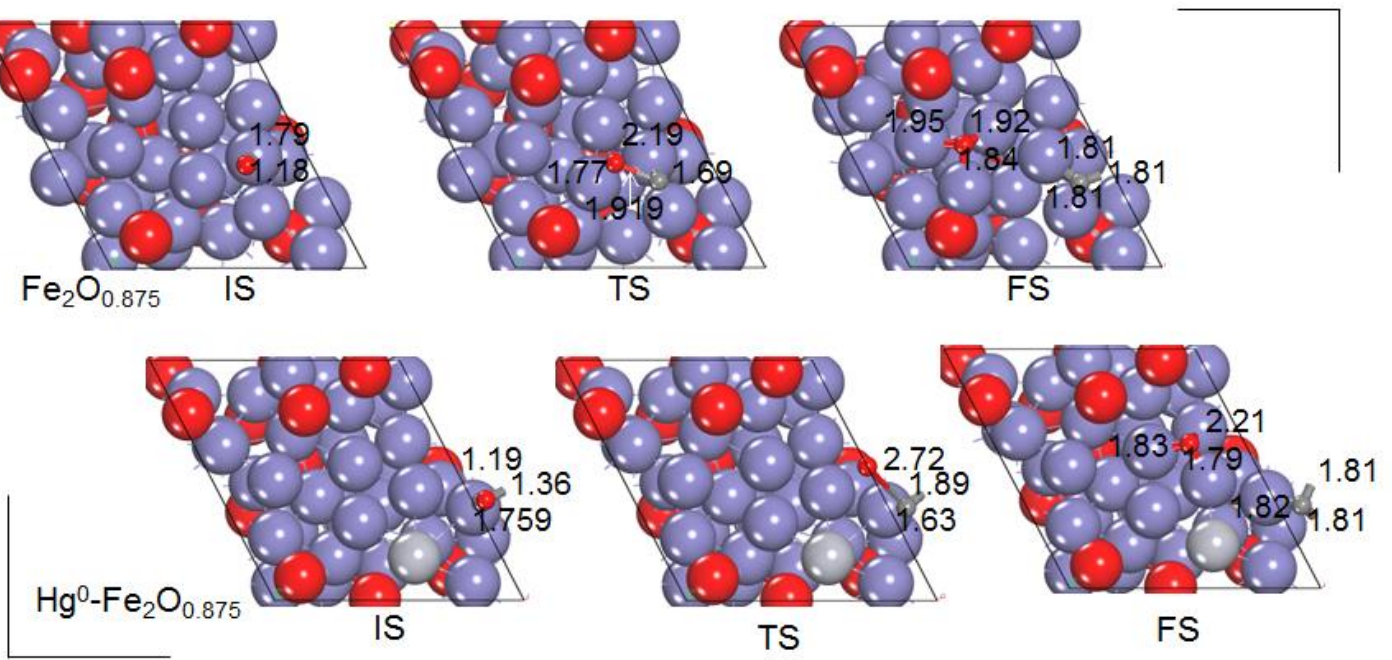

C

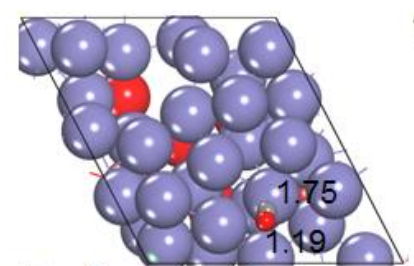

$\mathrm{Fe}_{2} \mathrm{O}_{0.375}$ IS

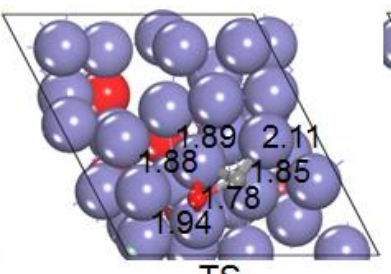

TS

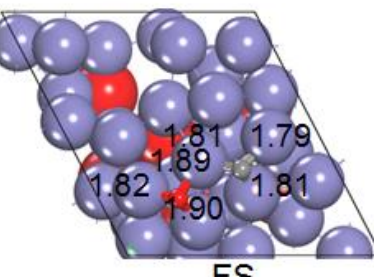

FS

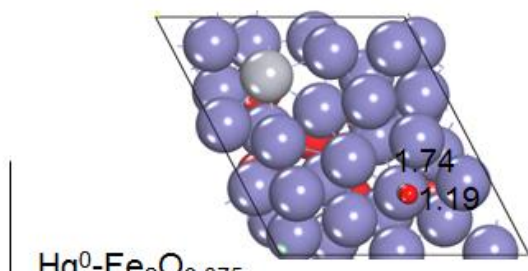

IS

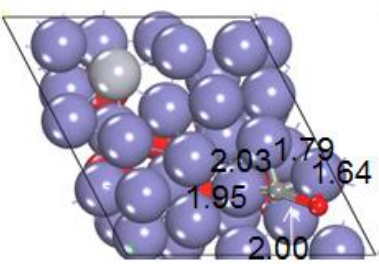

TS

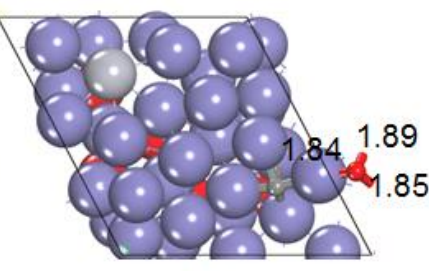

FS 
d

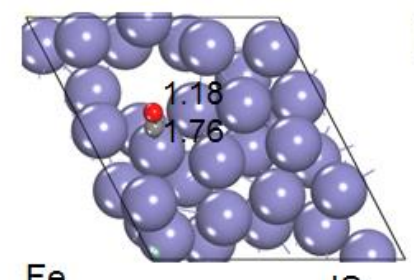

IS

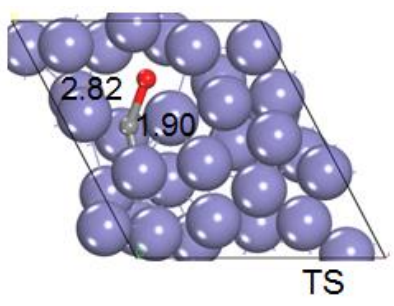

TS
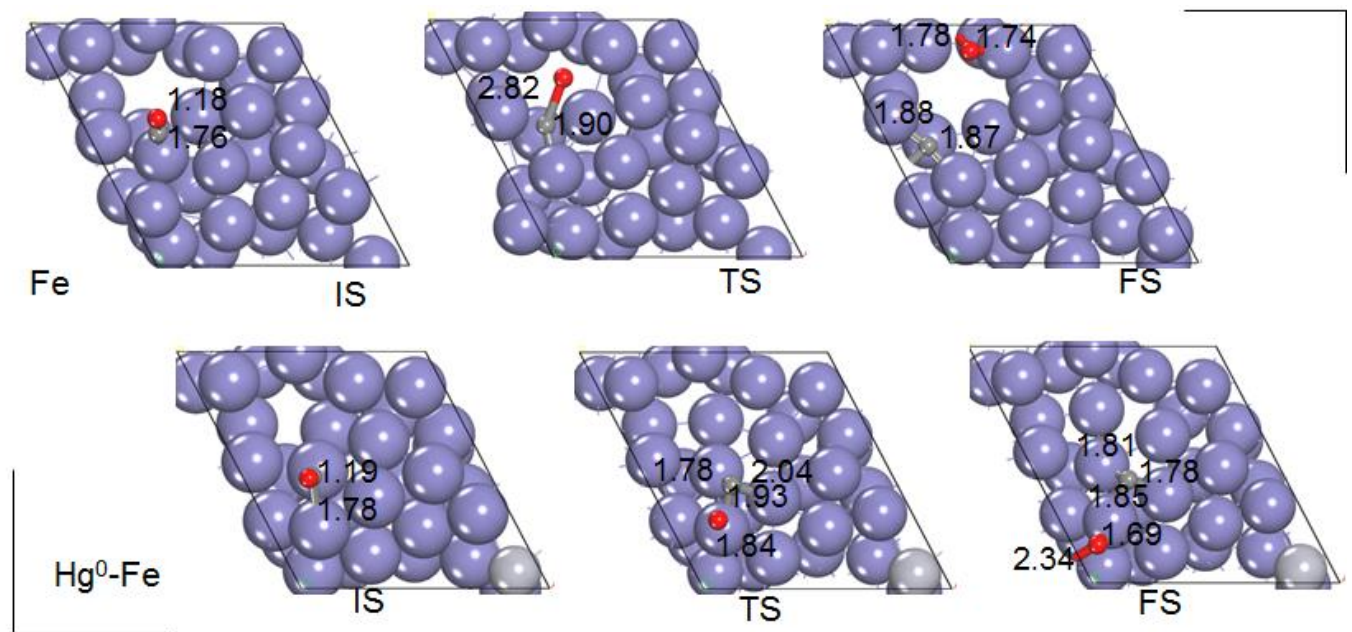

Fig.S2 Geometric structures of initial state (IS), transition state (TS), and final state (FS) for $\mathrm{CO}$ decomposition on (a) $\mathrm{Fe}_{2} \mathrm{O}_{1.625}$ and $\mathrm{Hg}^{0}-\mathrm{Fe}_{2} \mathrm{O}_{1.625}$, (b) $\mathrm{Fe}_{2} \mathrm{O}_{0.875}$ and $\mathrm{Hg}^{0}-\mathrm{Fe}_{2} \mathrm{O}_{0.875}$, (c) $\mathrm{Fe}_{2} \mathrm{O}_{0.375}$ and $\mathrm{Hg}^{0}-\mathrm{Fe}_{2} \mathrm{O}_{0.375}$, (d) $\mathrm{Fe}$ and $\mathrm{Hg}^{0}-\mathrm{Fe}$

The C-O bond length and the distance between $\mathrm{C}$ and Fe of the IS are given in $\AA$. And the related bond distances for the TS and FS are also given in $\AA$. 